\title{
MEASURING ECONOMICS RESEARCH IN THE CZECH REPUBLIC: A COMMENT
}

\author{
Daniel Münich
}
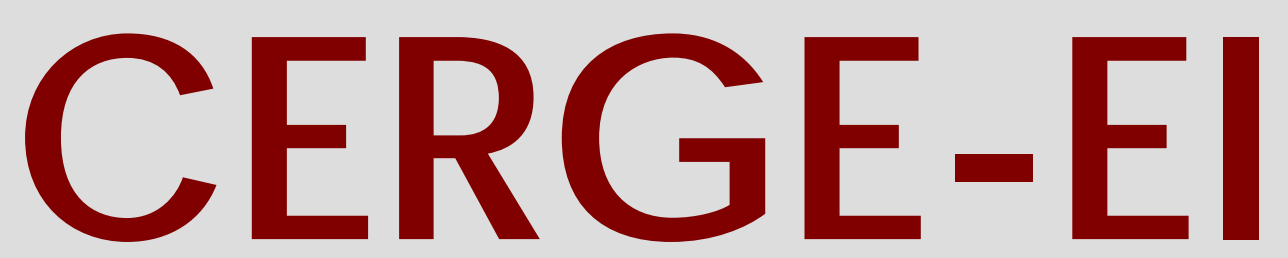

Charles University Centerfor Economic Research and Graduate Education Academy of Sciences of the Czech Republic Ec onomic Institute 


\title{
Working Paper Series $\quad 300$ (ISSN 1211-3298)
}

\section{Measuring Economics Research in the Czech Republic: A Comment}

\author{
Daniel Münich
}

\author{
CERGE-EI \\ Prague, July 2006
}


ISBN 80-7343-096-7 (Univerzita Karlova. Centrum pro ekonomický výzkum a doktorské studium) ISBN 80-7344-085-7 (Akademie věd České republiky. Národohospodářský ústav) 


\title{
Measuring Economics Research in the Czech Republic: A Comment
}

\author{
Daniel Münich
}

\author{
CERGE-EI*
}

July 2006

\begin{abstract}
Turnovec (2005) represents the first rigorous attempt to quantify and compare research of economists affiliated with Czech institutions as well as total output by these institutions. In this comment, I reconsider some of his results. My key finding is that a research-accounting methodology that closely reflects the widely differing quality of publications in economics leads to notably different results from those presented by Turnovec, who used an accounting scheme favoring quantity of publications over their quality.
\end{abstract}

\begin{abstract}
Abstrakt
Článek Turnovec (2005) představuje první rigorózní pokus kvantifikovat a porovnat výzkum ekonomů působících v českých institucích a výzkumné výstupy samotných institucí. V této obšírnější poznámce prrehodnocuji některé jeho výsledky. Mým hlavním zjištěním je skutečnost, že metodologie hodnocení výzkumu zohledňující významné rozdíly v kvalitě publikací vede k výsledkům, které se od těch prezentovaných Turnovcem výrazně odlišují $\mathrm{v}$ důsledku toho, že Turnovec použil metodologii extrémně zvýhodňující kvantitu publikací před jejich kvalitou.
\end{abstract}

Keywords: impact factor, publications, Czech Republic, research JEL classification: A10, A11

\footnotetext{
* CERGE-EI, Politických vězňů 7, Prague, Czech Republic. E-mail: Daniel.Munich@cerge-ei.cz CERGE-EI is a joint workplace of the Center for Economic Research and Graduate Education, Charles University, and the Economics Institute of the Academy of Sciences of the Czech Republic.
} 


\section{Introduction}

A recent paper by F. Turnovec (2005), published in an issue of Czech Journal of Economics and Finance focusing on measuring research output, represents the first rigorous attempt to quantify and compare research of economists affiliated with Czech institutions. In this note, I reconsider some of his results. I show that his methodology heavily favors quantity over quality of scientific outputs.

In an introductory article to the issue, Gregor and Schneider (GS) present 12 recent scio-metric studies in the field of economics, place the Turnovec paper into international perspective, and highlight the main choices he made in generating his rankings. In particular, they note that Turnovec uses an "extremely egalitarian approach" when summarizing research output across elite journals and low-impact outlets.

When comparing publications across different journals, most studies, including the paper by Turnovec, rely to some extent on impact factors (IF) ${ }^{1}$ of refereed journals. ${ }^{2}$ GS note that according to Turnovec's methodology, an article in a major international journal, American Economic Review, is "worth" only 1.8 times as much as an article in Politická ekonomie, a major national journal. This is due to the weighting scheme used by Turnovec who computes publication weight as

\footnotetext{
${ }^{1}$ According to the Web of Science (WoS), a journal's IF reflects the number of citations appearing in the Journal Citation Reports (JCR) in a given year of articles which have been published in a given journal over the past two years. An impact factor of 2.5 means that, on average, articles published one or two years ago in a given journal have been cited two and a half times.

${ }^{2}$ Referee process employed by impacted scientific journals is the only known systematic way to evaluate quality and relevance of research work in fields like economics.
} 


$$
(1+\text { impact factor }) /(\text { number of authors }) \text {. }
$$

Note that the formula adds 1 in the nominator to any publication and implies that even very low impact publications get weight roughly comparable to top international journals. ${ }^{3}$ This formula does not have reasonable foundations and its use, as I show here, leads to misleading findings and conclusions.

Even more striking is the choice of counting non-impact items (with IF $=0$ ) listed in the EconLit database towards research output. Turnovec considers an American Economic Review article to be 'worth' only about 3 times as much as any non-impact title, which include chapters in any book with an ISBN number as well as many types of working papers - that is even non-refereed internal publications of economics departments or international organizations. ${ }^{4}$ According to Turnovec, any two such publications are worth just as much as a paper in all journals with the IF of about 1.0, including for example the Journal of Development Economics or the Journal of Human Resources. ${ }^{5}$ Counting non-impact items multiplies the overall impact on the final results through the formula (1) by inappropriately assigning high weight to them.

\footnotetext{
${ }^{3}$ Only $1 / 4$ of all impacted journals in the field of Economics have IF $>1$.

${ }^{4}$ Although some research can have non-negligible impact already as a working paper, most of such work is eventually finally published in impacted journals, and thus captured by my methodology, which disregards a high number of low quality papers and working papers.

${ }^{5}$ Note that a given paper can first appear in EconLit within a working paper series (for example as a CEPR Discussion Paper) and then as a journal publication, resulting in a double entry. As for books, Neary et al. (2003) note the extreme variability in their scientific quality. Consider the example of the annual survey of the Czech economy produced by CERGE-EI. This 90-page booklet, co-authored by dozens of faculty members and students consists of dozens of short descriptions of different sectors of the economy and also presents summaries of selected CERGE-EI working papers. This publication clearly does not aspire to represent new scientific output; yet, each individual entry in the booklet is counted separately in EconLit.
} 
In stark contrast to Turnovec, most international scio-metric studies prefer IF-based weights that are an order of magnitude better in accounting for publication quality. For example, the weight of Politická ekonomie to American Economic Review would be 1:30 according to Dolado et al. (2003). Some of the studies go further and focus only on top publications, i.e., only top 10 or top 30 journals (Kalaitzidakis, et al., 1999, 2003). The 2003 symposium of the Journal of the European Economic Association on measuring research output considers only published journal articles and contrasts elitist and egalitarian weighting schemes, which differ mainly in the weight assigned to local and/or lesser journals. "The egalitarian weighting schemes value ten or twelve articles in such local journals as equivalent to an article in the prestigious American Economic Review. It seems unlikely that this weighting corresponds to those used by most European economists to rank their colleagues in other countries, or to the valuation that the profession worldwide places on contributions in different journals." (Neary et al., 2003). It is clear that the Turnovec weights, which count even non-journal publications, and which are even more egalitarian than the most egalitarian weights applied in the literature, do not lead to a summarizing measure of scientific output that would reflect the international competitiveness of Czech economics research.

The choice of a particular weighting scheme is always to some extent arbitrary. What should be the guiding principle of comparing publications across different types of outlets? First, a reason for giving high-IF journals a high relative weight is that most 
members of the profession never publish any papers in those journals. ${ }^{6}$ Second, the amount of time needed to generate a high-IF publication is typically of much greater magnitude compared to investment in generating a low-IF publication. A low quality weight would therefore penalize those focusing on high-quality publications and reward those churning out low-quality studies. Any research finance scheme based on egalitarian quality weights therefore actively encourages low-impact research. Third, all highly ranked economics departments in the world (including the few European toplevel institutions) count only publications in the very top set of journals when deciding on tenure decisions.

Hence, in this brief comment I offer an alternative set of publication rankings to those generated by Turnovec. ${ }^{7}$ Similar to Turnovec, I provide a list of top 50 economists and top 20 institutions based on total publications. In accordance with Dolado et al. (2003), I use the IF of a journal as the only relevant information. This means that I assign a zero weight to non-impact titles. ${ }^{8}$ I believe this to be consistent with the way the profession operates at the international level as any important result in economics is likely to find its way into one of the IF-journals. It is also consistent with the existing international scio-metric studies in the field of economics. I also compare several rankings based on minor variations in the journal quality weights and fields covered.

\footnotetext{
${ }^{6}$ While it is possible that one makes a major impact in the profession without publishing in major journals, such cases are exceptional and can therefore be ignored when devising a general research accounting scheme to be used for comparing economic departments.

${ }^{7}$ I do not re-evaluate his citation analysis. It would be ideal to recalculate all findings of Turnovec with an alternative weighting scheme. However, I was not able to obtain the data Turnovec uses and felt it redundant to re-create his database of research output. However, the sensitivity analysis presented here for publication records is sufficient to demonstrate the effect of the full use of quality weights.

${ }^{8}$ Contrary to Turnovec's weight $(1+I F)$ /\#authors, I am using IF/\#authors.
} 


\section{Data}

The full use of IF weights means that, in contrast to Turnovec, I can rely solely on the information available in the Social Sciences Citation Index (SSCI), available in the Web of Science (WoS). For comparability purposes, I pro-rate the weight of each publication according to the number of co-authors, ${ }^{9}$ and I also use Turnovec's set of affiliation and researcher selection criteria. ${ }^{10}$

I count only publications defined by the WoS as articles in English language published since 1994 (as in Turnovec, 2005) and extend the end period from 2003 to 2005. Articles published in Czech language only are not counted. Table 1 gives the abbreviations used for the institutions covered in this exercise. A list of journal abbreviations with IF levels and WoS fields is provided in the Appendix. I use the 2005 impact factors from the Journal Citation Reports database of the WoS. ${ }^{12}$ These are imprecise for older publications to the extent that past IF values for a given journal could have been higher or lower.

My database of authors was created as follows: I have searched the SSCI (WoS) database for all English-language articles of authors who appear in one of the two "Top50 " rankings of Turnovec as well as articles of authors who have at least one publication in "economics" or "business and finance" research fields in the WoS and

\footnotetext{
${ }^{9}$ Ascribing 1/n-th of a paper to the $n$ authors of that paper has been defended in Sauer (1988).

${ }^{10}$ Only main full-time-appointment positions are considered.

${ }^{12}$ Results based on JCR2003 are available at http://home.cerge.cuni.cz/munich/citations.html.
} 
who, at the same time, report affiliation in the Czech Republic. ${ }^{13}$ From the total collection of such articles, I have kept only those appearing in the research fields of "Economics," "Business and Finance," and related fields (see the Appendix for the list of SSCI field names).

"Economics" is often used as a general term covering both economics and business fields of research. Economics then includes the broad categories of micro- and macroeconomics as well as applied fields of labor and public economics, trade, industrial organization, game theory, and econometrics, etc. On the other hand, the quite separate business fields of management or accounting are typically not considered part of coreeconomics research. Despite a significant overlap, business schools and economics departments are separate programs in most developed countries, and economics and business school rankings are quite distinct. ${ }^{14}$ The overlap between economics and business research is strongest in the field of finance. In this paper, I first focus on core economics, including finance, and then extend the coverage to broad economics, which includes business and other related fields. It should be recognized that the importance of high-quality journal publications is arguably higher in economics than in the business profession.

My preferred ranking is based on impact factors only from core-economics journals, that is those that are categorized in the WoS as being in research fields which feature the

\footnotetext{
${ }^{13}$ Technically, the field Affiliation in WoS must contain the word "Czech".

${ }^{14}$ In the Czech Republic, there are both small "core-Economics" departments, such as CERGE-EI, and large schools covering both "Business" and "Economics" such as the Prague School of Economics.
} 
words "Economics," "Finance" and "Industrial" in their title. ${ }^{15}$ In the next step, I add the fields of "Business" and "Operations Research" as well as several fields closely related to economics, namely "Sociology," "Psychology," "Mathematics," "Statistics," and "Political Science."

\section{Results}

In table 2, I present the list of "Top 50" Czech economists based on the simple (coauthor pro-rated) summation of the impact factors of their publications during 1994 to 2005. The publication rank based on core-economics fields is given in column (4) and is used for sorting, while the underlying IF sum is provided in column (3) of the table. The total publication score of the first researcher is about 20 times higher than that of the $50^{\text {th }}$ economist based on IF sums. ${ }^{16}$

Next, I consider the importance of publications in broad-economics journals. In column (5), I provide an alternative publication ranking based on a more inclusive set of fields. For the most part, including the non core-economics fields has only a minor impact on

\footnotetext{
${ }^{15}$ The full list of journal field categories and their division into core-economics and broad-economics is given in the Appendix. It is clear that this division is to some extent arbitrary and depends, e.g., on the choice of wording in the field category names used in the WoS; hence, the sensitivity analysis.

${ }^{16}$ It should be noted that Table 2 lists also several authors who do not currently have full-time academic appointments in the Czech Republic (as required by the Turnovec affiliation criterion), but who have held such appointments sometime during 1994-2005. This additional author selection may be incomplete; it covers Z. Drábek, R. Podpiera, and M. Čihák (with a total IF of 0.36, 1.13, 0.91, respectively). There are also two very exceptional cases which I chose to exclude from the direct comparison of Table 2, even though they both belong in it based on the selection criteria used in this paper. First, consider J. Švejnar, an economist at the University of Michigan, who has held a full-time appointment in the Czech Republic during several of the sample-period years. While his total IF output in core-economic journals during 1994-2005 is much higher (at 7.89) than that of any Czech economist, this comparison reflects the clear order-of-magnitude difference between Czech and U.S. economics science. Second, another exceptional case is that of V. Klaus. He was included in the Turnovec list despite having spent the whole sample period as an active policy maker rather than as a publishing academic economist. The impact of economists active mainly in policy making is best evaluated using citations and his inclusion in publication-only rankings (with a total IF of 0.49) may therefore be viewed as unjust.
} 
the rankings. The few large 'jumps' in the rankings result in part from the fact that several high-quality journals in non-economics fields have IF levels of an order of magnitude higher than even the best core economics journal. ${ }^{17}$ It is an open question whether and how such publications are to be included in summaries of economics publications' impact factors. In general, it is equally possible that papers in noneconomics journals do fall within the field of economics or that they fall totally out of the field we study here and correspond to a previous scientific career in another field such as for example engineering. Similarly, it is often difficult to differentiate economics and sociology. Since objective rankings cannot be based on assigning individual papers within or outside the field of economics, I simply present both alternative approaches.

An important question is how sensitive such rankings are to variations in the researchaccounting formula. In order to focus on only prestigious, high-quality publications, I also generate another ranking, in which I ignore all journals with an IF below 0.3. This eliminates the bottom $1 / 4$ of journals in my broader list; among others, this eliminates all local journals. The purpose of this ranking is to focus on only mid-to-high-IF international journals. This also provides a better comparison to a number of other

\footnotetext{
${ }^{17}$ To illustrate some of the sensitivity, consider the case of A. Ortmann, whose (economics) papers appeared in Behavioral and Brain Sciences, a psychology field journal with a current impact factor of 9.9; this is a multiple of the American Economic Review of 1.8, one of the top core-economic journals. I also note that Turnovec does not distinguish the field of publication. Note that even different sub-fields included into my broad-economic field feature different levels of IF, which is given by, e.g., different citation practices. For example, the aforementioned journal Behavioral and Brain Sciences belongs to the WoS field of Psychology-Behavioral Sciences featuring the median IF 1.74, while a median journal in the research field of pure Economics has an IF of only 0.61 .
} 
previous studies. It is clear that only about $1 / 3$ of all articles I considered thus far were published in international core-economics journals with such higher IF.

Finally, the last column of table 2 gives the publication score ranking taken from table 4 of Turnovec (2005). It is clear that his ranking differs tremendously from those based on IF publications only. The majority of Top-50 Czech economists based on the preferred IF-only publication score were not included in Turnovec's Top-50 list and three of the researchers from the Turnovec Top-10 group are not in the Top-50 listing based on IFonly publications (V. Izák, F. Turnovec, and J. Večerník). Two of them would enter my Top-50 list based on the broad-economics field selection, but they all fall outside of the top 50 when only higher-IF journals are included. Finally, I note that there are several authors who do not appear in my "Top-50" according to publications in core-economics fields, but who rank $<50$ if broad-economics fields are considered. ${ }^{18}$

Table 3 summarizes the IF-accounting at the level of institutions, using the same variations on the accounting scheme that were used in table 3. Researcher affiliations are taken from Turnovec (2005) such that I also use the so-called research-stock publication accounting (see GS for a detailed discussion). Specifically, in columns (2) to (4), I present the total institution-level summations of co-author prorated impact factors based on the core-economics, broad-economics, and higher-IF-only journal selection described above. The next three columns, (5) to (7), scale these three output measures

\footnotetext{
${ }^{18} \mathrm{M}$. Zelený ranks highly in the Turnovec rankings primarily because of his major citation impact in operations research and mathematics journals. These journals are included in my broad-economics field group.
} 
by the number of researchers attached to each institution, again taken from Turnovec (2005).

While the ordering of institutions at the top of the publication list is similar to that of Turnovec (2005), the output gap between the leading and lagging institutions is of greater magnitude when using only IF publications. An 'average' CERGE-EI researcher published between 8 and 12 times as much "IF output" as the average economist in the second-highest ranking institution, the CNB, depending on the IF-sum measure used. The four top institutions - CERGE-EI, ČNB, UHK FIM and IES FSV UK produced 91, 84, and 92 percent of total "IF output," depending on the field and weight choice (columns 2, 3, 4), even though their share on total staff (see table 1) was a mere 9\%. It should be noted that both my and Turnovec's computations do not take into account possible changes in institutional affiliations of individual researchers during the 1994-2004 period. Also, both studies neglect differences in the average age of researchers, favoring institutions with above-average age of researchers, since younger researchers, who started their academic career after 1994, have had less time to publish. Nevertheless, it does not seem that any of these concerns would substantially alter my results.

To complete my sensitivity analysis, I also replicated my results using impact factors from JCR2003 (instead of JCR2005 being used here) and publications published during 
1994-2003 (instead of 1994-2005 being considered here). Those results differ only slightly from those presented here. ${ }^{19}$

\section{Conclusions}

Perhaps the key component of any modern empirical work is sensitivity analysis - the presentation of the degree of change in the main results with respect to the assumptions made when deriving them. There are a number of key choices one must make when generating research output summaries. While it is not practical to compare results across all combinations of the key choices, ${ }^{20}$ the lack of sensitivity analysis with respect to the weight assigned to high-quality journals in the Turnovec study is surprising. This is particularly worrisome given the extremely egalitarian quality weight applied by Turnovec, where any two, possibly non-refereed, non-impact publications are judged equivalent to one high-impact journal paper.

Measuring research output is an essential part of any public policy aimed at fostering high-quality research; it is therefore crucial that the methodology used for comparing research output across individuals or institutions be well understood. To this effect, this paper presents a comparison of a sub-set of the Turnovec rankings to ones more closely reflecting the differing quality of research output. While there is only minor sensitivity to several variations on the weighting scheme applied here, there is an extreme difference vis-à-vis the rankings generated by Turnovec (2005). In particular, the

\footnotetext{
${ }^{19}$ See http://home.cerge.cuni.cz/munich/citations.html.

${ }^{20}$ However, see Coupé (2003) for an extensive list of alternatives.

22 "Citations have the attraction of being article-specific, but the great disadvantage that they are subject to long and variable lags" (Neary et al. 2003). This disadvantage is particularly important in the field of modern economics, which is relatively new to the Czech science.
} 
majority of scientific output in the field of economics in impact-factor journals is concentrated in one institution, CERGE-EI. About a half of all Czech economics departments and institutions have had no single IF publication between 1994 and 2005.

An important caveat to the sensitivity analysis presented here is that, unlike Turnovec (2005), I do not compare publication-score rankings to citation rankings. Citations represent an important alternative to impact factors when measuring the quality of scientific output ${ }^{22}$ and future citation rankings should also more closely reflect the quality of journals in which citations occur. I expect the Turnovec citation rankings to be equally sensitive to full-IF quality adjustment as his impact-factor publication ratings.

The use of the Social Sciences Citation Index data allows one to generate such alternative rankings with relatively little effort. The criteria used to identify all relevant publications in the WoS are rigorous, but obviously there is the possibility of missing publications. In order to allow for corrections and to make this evaluation exercise transparent, I make all of my data publicly available. ${ }^{23}$ In the future, the use of such simple indices could serve as a useful addition to the set of tools used by government agencies when evaluating research output.

\footnotetext{
${ }^{23}$ See http://home.cerge.cuni.cz/munich/citations.html.
} 


\section{References}

Coupé, T. (2003). "Revealed Performances: Worldwide Rankings of Economists and Economics Departments, 1990-2000.” Journal of the European Economic Association, 1(6), pp. 1309-1345.

Dolado, J. J., A. Garcia-Romero, and G. Zamarro (2003), "Publishing performance in economics: Spanish rankings (1990-1999)”, Spanish Economic Review, 5 (2), 85-100.

Kalaitzidakis, Pantelis, Theofanis P. Mamuneas, and Thenasis Stengos (1999). "European Economics: An Analysis Based on Publications in the Core Journals." European Economic Review: Journal of the European Economic Association, 43, pp. $1150-1168$.

Kalaitzidakis, Pantelis, Theofanis P. Mamuneas, and Thenasis Stengos (2003). "Rankings of Academic Journals and Institutions in Economics." Journal of the European Economic Association, 1(6), pp. 1346-1366.

Neary, J. Peter, A. J. Mirrless, J. Tirole. (2003). Evaluating Economics Research in Europe: An introduction. Journal of the European Economic Association, 1(6), pp. 1239-1249.

Sauer, R. (1988), "Estimates of the Returns to Quality and Coautorship in Economic Academia“, Journal of Political Economy, vol. 96, no. 4, p. 855-866. 
Schneider, O. and Gregor, M. (2003). "The World is Watching: Rankings of Czech and Slovak Economics Departments", Finance a úvěr - Czech Journal of Economics and Finance, 55, no.11-12.

Turnovec, F. (2005). “Institucionální vědecký kapitál a individuální výkonnost ekonomů,“ Finance a úvěr - Czech Journal of Economics and Finance, 55, no.11-12. 
Table 1: Czech Academic Instituitions Doing Research in Economics

\begin{tabular}{llc}
\hline \multicolumn{1}{c}{ Institution } & Abbreviation & Researchers \\
\hline Centrum pro otázky životního prostředí UK & COZP UK & \\
CERGE-El & CERGE-EI & 21 \\
Česká národní banka & CNB & 54 \\
Česká zemědělská univerzita - Provozně ekonomická fakulta & CZU FPE & 111 \\
Fakulta sociálních věd Univerzity Karlovy - Institut ekonomických studii & UK FSV IES & 22 \\
Institut sociologických studií FSV UK & ISS FSV UK & \\
Jihočeská univerzita - ekonomické katedry Zemědělské fakulty & JCU FZ & 46 \\
Mendlova zemědělská a lesnická u. v Brně - Provozně ekonomická fakulta & MZU FPE & 75 \\
Masarykova univerzita - Fakulta sociálních věd & MU FSV & - \\
MU Brno - Fakulta ekonomicko-správní & MU ESF & 26 \\
NEWTON College & NEWTON Col & 4 \\
Škoda Auto College & SKODA Col & \\
Slezská univerzita Opava - Obchodně podnikatelská fakulta & SUO OPF & 42 \\
Sociologický ústav AV ČR & SoU AV CR & \\
Technická univerzita Liberec - Hospodářská fakulta & TUL HF & 36 \\
Univerzita Karlova - Ústav Blízkého východu a Afriky & UK UBVA & \\
Univerzita Hradec Králové - FIM & UHK FIM & 13 \\
Univerzita J.E. Purkyně - Fakulta sociálně-ekonomická & UJEP FSE & 29 \\
Univerzita Pardubice - Fakulta ekonomicko-správní & UP FES & 65 \\
Univerzita Tomáše Bati ve Zlíně - Fakulta managementu a ekonomiky & UTB FME & 57 \\
Ústav teorie informací a automatizace AV ČR & UTIA & 10 \\
VŠB Technická univerzita Ostrava - Ekonomická fakulta & VSB EF & 144 \\
VSE Fakulta financí a účetnictví & VSE FFU & 78 \\
VŠE Fakulta informatiky a statistiky & VSE FIS & 85 \\
VŠE Fakulta managementu & VSE FM & 35 \\
VŠE Fakulta mezinárodních vztahů & VSE FMV & 78 \\
VŠE Fakulta národohospodařská & VSE FNH & 38 \\
VŠE Fakulta podnikohospodářská & VSE FPH & 86 \\
Vysoká škola ekonomie a managementu - Centrum ekonomických studii & VSEM & 7 \\
Výzkumný ústav zemědělské ekonomiky & VUZE & - \\
Západočeská univerzita - Fakulta ekonomická & ZCU FE & 54 \\
\hline \hline & & \\
\hline
\end{tabular}

Data on researchers from Turnovec (2005). 
Table 2: Top 50 Economists with Czech Affiliation According to Impact Factor (1994-2005)

\begin{tabular}{|c|c|c|c|c|c|c|}
\hline \multirow[b]{2}{*}{ Author } & \multirow[b]{2}{*}{ Affiliation } & \multirow{2}{*}{$\begin{array}{l}\text { Total IF in } \\
\text { Core- } \\
\text { economics } \\
\text { Field } \\
\end{array}$} & \multicolumn{4}{|c|}{ Rankings } \\
\hline & & & $\begin{array}{c}\text { Core- } \\
\text { economics } \\
\text { Field }\end{array}$ & $\begin{array}{l}\text { Broad- } \\
\text { economics } \\
\text { Field }\end{array}$ & $\begin{array}{c}\text { Core- } \\
\text { economics } \\
\text { Field* }\end{array}$ & $\begin{array}{c}\text { Turnovec } \\
(2005)^{1)}\end{array}$ \\
\hline (1) & (2) & (3) & (4) & (5) & (6) & (7) \\
\hline Hanousek, J. & CERGE-EI & 5,33 & 1 & 2 & 1 & 3 \\
\hline Jurajda, S. & CERGE-EI & 4,19 & 2 & 4 & 2 & 25 \\
\hline Ortmann, A. & CERGE-EI & 3,51 & 3 & 1 & 3 & 8 \\
\hline Kejak, M. & CERGE-EI & 2,68 & 4 & 6 & 4 & . \\
\hline Jeong, BJ. & CERGE-EI & 2,63 & 5 & 7 & 5 & \\
\hline Kocenda, E. & CERGE-EI & 2,47 & 6 & 8 & 6 & 1 \\
\hline Zigic, K. & CERGE-EI & 1,82 & 7 & 12 & 7 & 43 \\
\hline Bohata, M. & Non-academic & 1,70 & 8 & 5 & 8 & 29 \\
\hline Duczynski, P. & UHK FIM & 1,68 & 9 & 16 & 9 & . \\
\hline Maleckova, J. & UK IMES & 1,31 & 10 & 19 & 10 & \\
\hline Lizal, L. & CERGE-EI & 1,26 & 11 & 20 & 11 & 35 \\
\hline Rydval, O. & CERGE-EI & 1,23 & 12 & 21 & 12 & . \\
\hline Babetskii, I. & CNB & 1,22 & 13 & 22 & 14 & \\
\hline Tuma, Z. & CNB & 1,15 & 14 & 25 & 13 & 40 \\
\hline Slobodyan, S. & CERGE-EI & 1,10 & 15 & 26 & 15 & . \\
\hline Sorm, V. & Non-academic & 1,08 & 16 & 27 & 16 & . \\
\hline Munich, D. & CERGE-El & 1,03 & 17 & 24 & 19 & . \\
\hline Derviz, A. & CNB & 0,95 & 18 & 28 & 17 & . \\
\hline Janackova, S. & CNB & 0,93 & 19 & 29 & 18 & . \\
\hline Zemplinerova, A. & CERGE-EI & 0,91 & 20 & 31 & 28 & \\
\hline Smidkova, K. & CNB & 0,86 & 21 & 32 & 24 & 12 \\
\hline Singer, M. & CNB & 0,86 & 22 & 33 & 20 & \\
\hline Janacek, $\mathrm{K}$. & Non-academic & 0,82 & 23 & 34 & 21 & 11 \\
\hline Dedek, O. & CNB & 0,81 & 24 & 36 & 25 & 6 \\
\hline Vlcek, K. & Unkown & 0,78 & 25 & 37 & 22 & \\
\hline Tomsik, V. & NEWTON Col & 0,72 & 26 & 38 & 23 & 4 \\
\hline Cincibuch, M. & CNB & 0,66 & 27 & 40 & 50 & . \\
\hline Sirovatka, T. & MU FSV & 0,58 & 28 & 42 & 49 & . \\
\hline Vintrova, R. & VSEM & 0,58 & 29 & 43 & 36 & \\
\hline Benacek, V. & UK FSV IES & 0,57 & 30 & 44 & 26 & 15 \\
\hline Holub, $\mathrm{T}$. & CNB & 0,55 & 31 & 45 & 31 & 7 \\
\hline Katuscak, P. & CERGE-EI & 0,53 & 32 & 46 & 27 & \\
\hline Kotlan, V. & VSB EF & 0,48 & 33 & 47 & 43 & 19 \\
\hline Druska, V. & Non-academic & 0,48 & 34 & 48 & 29 & \\
\hline Jilek, J. & VSE FIS & 0,46 & 35 & 49 & 30 & 18 \\
\hline Komarek, L. & CNB & 0,41 & 36 & 50 & 32 & 14 \\
\hline Hak, T. & COZP UK & 0,39 & 37 & 55 & 34 & $\cdot$ \\
\hline Kovanda, J. & Unkown & 0,39 & 38 & 56 & 35 & . \\
\hline Scasny, M. & COZP UK & 0,39 & 39 & 57 & 33 & \\
\hline Zidek, L. & MU ESF & 0,38 & 40 & 58 & 191 & 31 \\
\hline Chlumsky, J. & VSE FMV & 0,38 & 41 & 59 & 37 & \\
\hline Janda, K. & UK FSV IES & 0,37 & 42 & 13 & 98 & 27 \\
\hline Kostova, D. & Unkown & 0,36 & 43 & 61 & 39 & r \\
\hline Kuchar, P. & Unkown & 0,36 & 44 & 62 & 38 & . \\
\hline Doucha, T. & RIAE & 0,32 & 45 & 63 & 40 & . \\
\hline Melecky, M. & Czech abroad & 0,31 & 46 & 64 & 41 & . \\
\hline Zamrazilova, E. & Non-academic & 0,31 & 47 & 65 & 46 & \\
\hline Mertlik, P. & Unkown & 0,31 & 48 & 66 & 44 & 49 \\
\hline Erbenova, M. & CNB & 0,31 & 49 & 68 & 47 & . \\
\hline Dvorak, T. & Unkown & 0,31 & 50 & 70 & 45 & \\
\hline
\end{tabular}

${ }^{*}$ Excludes journals with $I F<.3$

1) Dots represent researchers not included in Turnovec's publications ranking. 
Table 3: Ranking of Czech Academic Institutions Doing Research in Economics

\begin{tabular}{|c|c|c|c|c|c|c|c|c|}
\hline \multirow{3}{*}{ Rank } & \multirow[b]{2}{*}{ Institution } & \multicolumn{3}{|c|}{$\begin{array}{c}\text { IF sum } \\
\text { Economics Field Group }\end{array}$} & \multicolumn{3}{|c|}{$\begin{array}{l}\text { IF sum per researcher } \\
\text { Economics Field Group }\end{array}$} & \multirow{2}{*}{$\begin{array}{c}\text { Rank } \\
\text { Turnovec } \\
(2005)\end{array}$} \\
\hline & & Core & Broad & Core $^{*}$ & Core & Broad & Core* & \\
\hline & (1) & (2) & (3) & (4) & (5) & (6) & (7) & (8) \\
\hline 1 & CERGE-EI & 30,08 & 50,66 & 27,49 & 1,43 & 2,41 & 1,31 & 1 \\
\hline 2 & CNB & 9,89 & 10,29 & 8,26 & 0,18 & 0,19 & 0,15 & 3 \\
\hline 3 & UHK FIM & 1,68 & 1,68 & 1,51 & 0,13 & 0,13 & 0,12 & 9 \\
\hline 4 & UK FSV IES & 2,12 & 5,81 & 0,57 & 0,10 & 0,26 & 0,03 & 2 \\
\hline 5 & VSB EF & 0,73 & 2,37 & 0,31 & 0,01 & 0,02 & 0,00 & 11 \\
\hline 6 & VSE FMV & 0,57 & 0,57 & 0,57 & 0,01 & 0,01 & 0,01 & 8 \\
\hline 7 & VSE FIS & 0,46 & 1,68 & 0,46 & 0,01 & 0,02 & 0,01 & 7 \\
\hline . & VSE FNH & 0,46 & 0,46 & 0,46 & 0,01 & 0,01 & 0,01 & 5 \\
\hline . & MU ESF & 0,38 & 0,38 & 0,00 & 0,01 & 0,01 & 0,00 & 10 \\
\hline . & VSE FFU & 0,25 & 0,25 & 0,25 & 0,00 & 0,00 & 0,00 & 6 \\
\hline . & SUO OPF & 0,17 & 0,17 & 0,00 & 0,00 & 0,00 & 0,00 & 17 \\
\hline . & UTIA & 0,00 & 3,34 & 0,00 & 0,00 & 0,33 & 0,00 & 4 \\
\hline . & UTB FME & 0,00 & 2,06 & 0,00 & 0,00 & 0,04 & 0,00 & 18 \\
\hline . & ZCU FE & 0,00 & 0,00 & 0,00 & 0,00 & 0,00 & 0,00 & 22 \\
\hline . & UP FES & 0,00 & 0,00 & 0,00 & 0,00 & 0,00 & 0,00 & 21 \\
\hline . & JCU FZ & 0,00 & 0,00 & 0,00 & 0,00 & 0,00 & 0,00 & 15 \\
\hline . & VSE FM & 0,00 & 0,00 & 0,00 & 0,00 & 0,00 & 0,00 & 13 \\
\hline . & CZU FPE & 0,00 & 0,00 & 0,00 & 0,00 & 0,00 & 0,00 & 16 \\
\hline . & UJEP FSE & 0,00 & 0,00 & 0,00 & 0,00 & 0,00 & 0,00 & 19 \\
\hline . & VSE FPH & 0,00 & 0,00 & 0,00 & 0,00 & 0,00 & 0,00 & 12 \\
\hline . & MZU FPE & 0,00 & 0,00 & 0,00 & 0,00 & 0,00 & 0,00 & 20 \\
\hline & TUL HF & 0,00 & 0,00 & 0,00 & 0,00 & 0,00 & 0,00 & 14 \\
\hline ** & NEWTON Col & 0,72 & 0,72 & 0,72 & 0,18 & 0,18 & 0,18 & . \\
\hline$\star \star \star$ & VSEM & 0,84 & 0,84 & 0,64 & 0,12 & 0,12 & 0,09 & \\
\hline
\end{tabular}

* Excludes journals with IF<.3

** Institutions not included into the rankings of Turnovec due to their small size. 
Table A1: List of IF-journals in the Database (IF from the JCR 2005).

\begin{tabular}{|c|c|c|c|c|c|}
\hline Journal & $\begin{array}{l}\text { Impact } \\
\text { Factor }\end{array}$ & Field & Journal & $\begin{array}{l}\text { Impact } \\
\text { Factor }\end{array}$ & Field \\
\hline BEHAV BRAIN SCI & 9,885 & 57 & PUBLIC ADMIN DEVELOP & 0,53 & 66 \\
\hline J ECON PERSPECT & 2,63 & 19 & LABOUR ECON & 0,53 & 19 \\
\hline J BUS VENTURING & 1,85 & 2 & SMALL BUS ECON & 0,53 & 19 \\
\hline AM ECON REV & 1,81 & 19 & ANN OPER RES & 0,53 & 50 \\
\hline EUR J POLIT RES & 1,78 & 53 & ECON MODEL & 0,51 & 19 \\
\hline J THEOR POLIT & 1,69 & 53 & PUBLIC CHOICE & 0,50 & 29 \\
\hline J ECONOMETRICS & 1,58 & 47 & ENVIRON RESOUR ECON & 0,49 & 22 \\
\hline REV ECON STAT & 1,52 & 62 & REV ECON DYNAM & 0,48 & 19 \\
\hline ECON J & 1,44 & 19 & KYKLOS & 0,47 & 19 \\
\hline INT ECON REV & 1,28 & 19 & PROC AMER MATH SOC & 0,43 & 45 \\
\hline SOCIOL EDUC & 1,22 & 34 & SOCIOL QUART & 0,43 & 63 \\
\hline ECOL ECON & 1,18 & 67 & STUD NONLINEAR DYN E & 0,42 & 62 \\
\hline WORK EMPLOY SOC & 1,10 & 27 & NONPROF VOLUNT SEC C & 0,41 & 60 \\
\hline J COMP ECON & 1,09 & 19 & EUROPE-ASIA STUD & 0,39 & 65 \\
\hline RURAL SOCIOL & 1,07 & 63 & ECON LETT & 0,38 & 19 \\
\hline J HUM RESOUR & 1,07 & 26 & ANN I STAT MATH & 0,38 & 64 \\
\hline FUZZY SET SYST & 1,04 & 18 & Z ANGEW MATH MECH & 0,351 & 46 \\
\hline EUR REV AGRIC ECON & 0,98 & 1 & MANCH SCH & 0,319 & 19 \\
\hline IND LABOR RELAT REV & 0,97 & 38 & J FUTURES MARKETS & 0,317 & 3 \\
\hline AM J AGR ECON & 0,97 & 1 & FUND MATH & 0,312 & 43 \\
\hline EUR ECON REV & 0,96 & 19 & EASTERN EUR ECON & 0,311 & 19 \\
\hline SPORT PSYCHOL & 0,94 & 56 & APPL ECON & 0,303 & 19 \\
\hline J ECON SURV & 0,91 & 19 & COMPUTATION STAT & 0,286 & 64 \\
\hline J DEV ECON & 0,87 & 19 & POST-COMMUNIST ECON & 0,276 & 19 \\
\hline J ECON PSYCHOL & 0,85 & 30 & COMMUNIS POST-COMML & 0,273 & 39 \\
\hline EUR J OPER RES & 0,82 & 50 & WORLD POLICY J & 0,267 & 39 \\
\hline INT STAT REV & 0,80 & 64 & EMERG MARK FINANC TR & 0,259 & 5 \\
\hline J ECON BEHAV ORGAN & 0,78 & 19 & SOUTH ECON J & 0,259 & 19 \\
\hline OXFORD ECON PAP & 0,78 & 19 & MATH METHOD OPER RE؟ & 0,259 & 68 \\
\hline ECON TRANSIT & 0,77 & 19 & RATION SOC & 0,235 & 63 \\
\hline COMPUT STAT DATA AN & 0,73 & 16 & APPL ECON LETT & 0,227 & 19 \\
\hline ECON INQ & 0,72 & 19 & EKON CAS & 0,204 & 19 \\
\hline J ECON DYN CONTROL & 0,69 & 19 & J INST THEOR ECON & 0,195 & 19 \\
\hline J AGR ECON & 0,67 & 1 & SOCIOLOGIA & 0,195 & 63 \\
\hline J BUS ETHICS & 0,64 & 6 & POLIT EKON & 0,193 & 29 \\
\hline PARTY POLIT & 0,64 & 53 & GENEVA PAP R I-ISS P & 0,192 & 3 \\
\hline SCAND J ECON & 0,62 & 19 & FINANC UVER & 0,173 & 3 \\
\hline INSUR MATH ECON & 0,61 & 48 & INT J GAME THEORY & 0,169 & 48 \\
\hline INT TAX PUBLIC FINAN & 0,60 & 3 & J ECON EDUC & 0,164 & 21 \\
\hline POLIT STUD-LONDON & 0,58 & 53 & NEW REPUBLIC & 0,145 & 53 \\
\hline J COMPUT APPL MATH & 0,57 & 44 & CAH PSYCHOL COGN & 0,138 & 58 \\
\hline MON LABOR REV & 0,54 & 37 & SOCIOL CAS & 0,113 & 63 \\
\hline \multirow[t]{2}{*}{ ECON DEV CULT CHANGE } & 0,53 & 20 & AM J ECON SOCIOL & 0,094 & 32 \\
\hline & & & J POLIT MIL SOC & 0,069 & 54 \\
\hline
\end{tabular}

Note: Listed are only IF-journals which appear at least once in the working databases of Czech affiliated authors. 
Table A2: List of Fields

\begin{tabular}{|c|c|c|c|}
\hline \multirow{2}{*}{ id } & \multirow{2}{*}{ Field Name } & \multicolumn{2}{|c|}{ Field Group } \\
\hline & & Core & Broad \\
\hline 1 & Agricultural Economics \& Policy; Economics & yes & yes \\
\hline 2 & Business & no & yes \\
\hline 3 & Business, Finance & yes & yes \\
\hline 5 & Business; International Relations & no & yes \\
\hline 5 & Business, International Relations & no & yes \\
\hline 6 & Business; Ethics & no & yes \\
\hline 10 & Computer Science, Artificial Intelligence & no & no \\
\hline 11 & Computer Science, Cybernetics & no & no \\
\hline 12 & Computer Science, Cybernetics; Automation \& Control Systems & no & no \\
\hline 13 & Computer Science, Information Systems & no & no \\
\hline 15 & Computer Science, Interdisciplinary Applications; Information Science \& Library & no & no \\
\hline 16 & Computer Science, Interdisciplinary Applications; Statistics \& Probability & no & yes \\
\hline 18 & Computer Science, Theory \& Methods; Mathematics, Applied; Statistics \& Probabili & no & yes \\
\hline 19 & Economics & yes & yes \\
\hline 20 & Economics; Area Studies; Planning And Development & yes & yes \\
\hline 21 & Economics; Education \& Educational Research & yes & yes \\
\hline 22 & Economics; Environmental Studies & yes & yes \\
\hline 24 & Economics; Geography & yes & yes \\
\hline 25 & Economics; History Of Social Sciences & yes & yes \\
\hline 26 & Economics; Industrial Relations \& Labor & yes & yes \\
\hline 27 & Economics; Industrial Relations \& Labor; Sociology & yes & yes \\
\hline 29 & Economics; Political Science & yes & yes \\
\hline 30 & Economics; Psychology, Multidisciplinary & yes & yes \\
\hline 32 & Economics; Sociology & yes & yes \\
\hline 33 & Education \& Educational Research & no & no \\
\hline 34 & Education \& Educational Research; Sociology & no & yes \\
\hline 37 & Industrial Relations \& Labor & yes & yes \\
\hline 38 & Industrial Relations and Labor & yes & yes \\
\hline 39 & International Relations; Political Science & no & yes \\
\hline 42 & Materials Science, Multidisciplinary; Physics, Applied; Optics & no & no \\
\hline 43 & Mathematics & no & yes \\
\hline 44 & Mathematics, Applied & no & yes \\
\hline 45 & Mathematics, Applied; Mathematics & no & yes \\
\hline 46 & Mathematics, Applied; Mechanics & no & yes \\
\hline 48 & Mathematics, Economics; Statistics \& Probability, Interdisc Applications; Social Sciences & yes & yes \\
\hline 50 & Operations Research \& Management Science & no & yes \\
\hline 53 & Political Science & no & yes \\
\hline 54 & Political Science; Sociology & no & yes \\
\hline 55 & Psychiatry; Substance Abuse & no & no \\
\hline 56 & Psychology, Applied; Psychology; Sport Sciences & no & yes \\
\hline 57 & Psychology, Biological; Behavioral Sciences; Neurosciences & no & yes \\
\hline 58 & Psychology, Experimental & no & yes \\
\hline 59 & Public Administration & no & yes \\
\hline 60 & Social Issues & no & yes \\
\hline 62 & Social Sciences, Mathematical Methods; Economics & yes & yes \\
\hline 63 & Sociology & no & yes \\
\hline 64 & Statistics \& Probability & no & yes \\
\hline 65 & Area Studies; Economics; Political Science & yes & yes \\
\hline 66 & Planning And Development; Public Administration & no & yes \\
\hline 67 & Ecology; Economics; Environmental Sciences & yes & yes \\
\hline 68 & Mathematics, Applied; Operations Research \& Management Science & no & yes \\
\hline
\end{tabular}

Note: Listed are only fields which appear at least once in my database of publications. 
Table A3: List of Authors and Their Publications in IF-journals During 1994-2005

\begin{tabular}{|c|c|c|c|c|c|}
\hline Author & Journal & Year & Author & Journal & Year \\
\hline$\overline{\text { Arlt, J. }}$ & INT STAT REV & 2005 & Erbenova, M. & SCAND J ECON & 1999 \\
\hline Babetskii, I. & J COMP ECON & 2004 & Fiala, P. & ENVIRON RESOUR EC & 2003 \\
\hline Babetskii, I. & ECON TRANSIT & 2005 & Fischer, $\mathrm{M}$. & EASTERN EUR ECON & 1995 \\
\hline Babetskii, I. & FINANC UVER & 2005 & Flek, V. & FINANC UVER & 2002 \\
\hline Bauer, $\mathrm{P}$. & INT J GAME THEORY & 1995 & Flek, V. & FINANC UVER & 2003 \\
\hline Bauer, P. & FINANC UVER & 2004 & Flek, V. & FINANC UVER & 2005 \\
\hline Benacek, V. & EASTERN EUR ECON & 1995 & Frait, J. & EASTERN EUR ECON & 2000 \\
\hline Benacek, V. & SMALL BUS ECON & 1995 & Fukac, M. & FINANC UVER & 2005 \\
\hline Bezdek, V. & FINANC UVER & 2003 & Galuscak, K. & FINANC UVER & 2005 \\
\hline Bezdek, V. & FINANC UVER & 2003 & Gersl, A. & FINANC UVER & 2004 \\
\hline Bizikova, L. & EKON CAS & 2004 & Gottvald, J. & FINANC UVER & 2005 \\
\hline Blazek, L. & AM J ECON SOCIOL & 2000 & Gregor, M. & FINANC UVER & 2005 \\
\hline Bohacek, R. & SOUTH ECON J & 2002 & Hak, T. & ECOL ECON & 2003 \\
\hline Bohata, M. & EASTERN EUR ECON & 1995 & Hanousek, J. & EASTERN EUR ECON & 1995 \\
\hline Bohata, M. & J BUS ETHICS & 1997 & Hanousek, J. & EASTERN EUR ECON & 1995 \\
\hline Bohata, M. & EASTERN EUR ECON & 1998 & Hanousek, J. & APPL ECON & 1998 \\
\hline Bohata, M. & EASTERN EUR ECON & 1998 & Hanousek, J. & POLIT EKON & 1999 \\
\hline Bohata, M. & EASTERN EUR ECON & 1998 & Hanousek, J. & ECON TRANSIT & 2000 \\
\hline Bohata, M. & EASTERN EUR ECON & 1998 & Hanousek, J. & EUR ECON REV & 2001 \\
\hline Bohata, M. & EASTERN EUR ECON & 1998 & Hanousek, J. & ECON TRANSIT & 2002 \\
\hline Bohata, M. & J BUS VENTURING & 1999 & Hanousek, J. & J COMP ECON & 2002 \\
\hline Brom, $\mathrm{K}$. & EUROPE-ASIA STUD & 1994 & Hanousek, J. & ECON TRANSIT & 2002 \\
\hline Cabelkova, I. & APPL ECON & 2004 & Hanousek, J. & J ECON PERSPECT & 2002 \\
\hline Cerna, A. & EASTERN EUR ECON & 1995 & Hanousek, J. & J COMP ECON & 2003 \\
\hline Cetkovsky, P. & EASTERN EUR ECON & 1995 & Hanousek, J. & KYKLOS & 2004 \\
\hline Chalupka, R. & FINANC UVER & 2004 & Hanousek, J. & APPL ECON & 2004 \\
\hline Chlumsky, J. & ECON TRANSIT & 1997 & Hanousek, J. & ECON LETT & 2004 \\
\hline Chvojka, P. & EKON CAS & 1997 & Hanousek, J. & ECON DEV CULT CHAI & 2004 \\
\hline Cihak, M. & EASTERN EUR ECON & 1997 & Havel, J. & POLIT EKON & 1995 \\
\hline Cihak, M. & EASTERN EUR ECON & 1998 & Havlik, P. & EUR J OPER RES & 2001 \\
\hline Cihak, M. & FINANC UVER & 1999 & Havlik, P. & EUR REV AGRIC ECON & 2005 \\
\hline Cinak, M. & FINANC UVER & 2003 & Hedbavny, P. & FINANC UVER & 2003 \\
\hline Cihak, M. & FINANC UVER & 2003 & Holicky, P. & FUND MATH & 2000 \\
\hline Cihak, M. & FINANC UVER & 2005 & Holub, T. & EASTERN EUR ECON & 1998 \\
\hline Cincibuch, $\mathrm{M}$. & FINANC UVER & 2002 & Holub, T. & EASTERN EUR ECON & 2000 \\
\hline Cincibuch, $\mathrm{M}$. & FINANC UVER & 2002 & Holub, T. & FINANC UVER & 2003 \\
\hline Cincibuch, M. & J FUTURES MARKETS & 2004 & Hraba, J. & RURAL SOCIOL & 1999 \\
\hline Cincibuch, $\mathrm{M}$. & FINANC UVER & 2004 & Hraba, J. & J POLIT MIL SOC & 2001 \\
\hline Davidova, S. & J AGR ECON & 2003 & Hraba, J. & SOCIOL QUART & 2001 \\
\hline Davidova, S. & POST-COMMUNIST ECON & 2003 & Hraba, J. & SOCIOL EDUC & 2002 \\
\hline Dedek, O. & POLIT EKON & 1995 & Hrncir, M. & EASTERN EUR ECON & 2000 \\
\hline Dedek, O. & EASTERN EUR ECON & 1995 & Hurnik, J. & FINANC UVER & 2005 \\
\hline Dedek, O. & EASTERN EUR ECON & 2004 & Huskova, M. & J ECON DYN CONTRO & 2003 \\
\hline Derviz, A. & EUR ECON REV & 2004 & Izak, V. & EASTERN EUR ECON & 1995 \\
\hline Doucha, $\mathrm{T}$. & EUR REV AGRIC ECON & 1999 & Janacek, $\mathrm{K}$. & EASTERN EUR ECON & 1994 \\
\hline Drabek, Z. & J COMP ECON & 1994 & Janacek, K. & J COMP ECON & 1994 \\
\hline Druska, V. & AM J AGR ECON & 2004 & Janacek, K. & EASTERN EUR ECON & 1997 \\
\hline Duczynski, P. & J ECON DYN CONTROL & 2002 & Janackova, S. & EASTERN EUR ECON & 1995 \\
\hline Duczynski, P. & ECON MODEL & 2003 & Janackova, S. & EASTERN EUR ECON & 1996 \\
\hline Duczynski, P. & EASTERN EUR ECON & 2005 & Janackova, S. & EASTERN EUR ECON & 2000 \\
\hline Duczynski, P. & FINANC UVER & 2005 & Janda, J. & J AGR ECON & 2000 \\
\hline Dupacova, J. & MATH METHOD OPER RES & 1999 & Janda, K. & J THEOR POLIT & 1994 \\
\hline Dupacova, J. & ANN OPER RES & 2000 & Janda, K. & PARTY POLIT & 1995 \\
\hline Dupacova, J. & EUR J OPER RES & 2001 & Janda, $\mathrm{K}$. & POLIT STUD-LONDON & 1998 \\
\hline Dupacova, J. & EUR J OPER RES & 2002 & Janda, $\mathrm{K}$. & FINANC UVER & 2002 \\
\hline Dupacova, J. & J ECON DYN CONTROL & 2003 & Janda, K. & EMERG MARK FINANC & 2004 \\
\hline Dusek, L. & FINANC UVER & 2002 & Janda, K. & EKON CAS & 2005 \\
\hline Dvorak, A. & ENVIRON RESOUR ECON & 2003 & Jeong, BJ. & J DEV ECON & 2002 \\
\hline Dvorak, T. & EASTERN EUR ECON & 1997 & Jeong, BJ. & INT ECON REV & 2002 \\
\hline Dyba, K. & EASTERN EUR ECON & 1999 & Jeong, BJ. & REV ECON DYNAM & 2003 \\
\hline
\end{tabular}


Table A3: (continued)

\begin{tabular}{|c|c|c|c|c|c|}
\hline Author & Journal & Year & Author & Journal & Year \\
\hline Jezek, M. & FINANC UVER & 2003 & Mandl, P. & INSUR MATH ECON & 1996 \\
\hline Jilek, J. & EASTERN EUR ECON & 1998 & Marcek, D. & EKON CAS & 2003 \\
\hline Jilek, J. & EASTERN EUR ECON & 2000 & Mares, M. & FUZZY SET SYST & 1997 \\
\hline Jilkova, J. & EASTERN EUR ECON & 1998 & Mares, M. & FUZZY SET SYST & 1997 \\
\hline Jurajda, S. & LABOUR ECON & 1999 & Mares, M. & FUZZY SET SYST & 2000 \\
\hline Jurajda, S. & J ECONOMETRICS & 2002 & Mares, $\mathrm{P}$. & SOCIOLOGIA & 1997 \\
\hline Jurajda, S. & IND LABOR RELAT REV & 2003 & Mares, $\mathrm{P}$. & FINANC UVER & 2005 \\
\hline Jurajda, S. & FINANC UVER & 2003 & Markova, L. & FINANC UVER & 2002 \\
\hline Jurajda, S. & J COMP ECON & 2003 & Markova, L. & FINANC UVER & 2003 \\
\hline Jurajda, S. & ECON TRANSIT & 2003 & Matalik, I. & INT STAT REV & 2005 \\
\hline Jurajda, S. & APPL ECON LETT & 2004 & Mazurova, L. & INSUR MATH ECON & 1996 \\
\hline Jurajda, S. & FINANC UVER & 2005 & Melecky, M. & EASTERN EUR ECON & 2003 \\
\hline Kankova, V. & J COMPUT APPL MATH & 1994 & Melecky, M. & EASTERN EUR ECON & 2004 \\
\hline Kankova, V. & Z ANGEW MATH MECH & 1997 & Mertlik, P. & EASTERN EUR ECON & 1997 \\
\hline Katuscak, P. & J HUM RESOUR & 2005 & Mizik, T. & POST-COMMUNIST EC & 2003 \\
\hline Kejak, M. & J ECON DYN CONTROL & 2003 & Mladek, J. & WORLD POLICY J & 1995 \\
\hline Kejak, M. & ECON TRANSIT & 2003 & Mladek, J. & J BUS VENTURING & 1999 \\
\hline Kejak, M. & ECON INQ & 2004 & Munich, D. & FINANC UVER & 2003 \\
\hline Kejak, M. & REV ECON DYNAM & 2005 & Munich, D. & EMERG MARK FINANC & 2004 \\
\hline Kejak, M. & MANCH SCH & 2005 & Munich, D. & REV ECON STAT & 2005 \\
\hline Kejak, M. & J ECON SURV & 2005 & Munich, D. & J COMP ECON & 2005 \\
\hline Kejak, M. & ECON J & 2005 & Munich, D. & FINANC UVER & 2005 \\
\hline Klapka, J. & EUR J OPER RES & 2002 & Navratil, D. & FINANC UVER & 2003 \\
\hline Klaus, V. & PUBLIC CHOICE & 1998 & Navratil, D. & FINANC UVER & 2005 \\
\hline Klazar, S. & INT TAX PUBLIC FINAN & 2001 & Navratil, D. & FINANC UVER & 2005 \\
\hline Klokocnik, O. & EASTERN EUR ECON & 1995 & Novotny, F. & POLIT EKON & 2004 \\
\hline Klvacova, E. & EUROPE-ASIA STUD & 1996 & Ortmann, A. & INT J GAME THEORY & 1995 \\
\hline Knot, O. & FINANC UVER & 2005 & Ortmann, A. & NONPROF VOLUNT SE & 1996 \\
\hline Kocenda, E. & EASTERN EUR ECON & 1996 & Ortmann, A. & RATION SOC & 1996 \\
\hline Kocenda, E. & ECON TRANSIT & 1998 & Ortmann, A. & RATION SOC & 1996 \\
\hline Kocenda, E. & EASTERN EUR ECON & 1999 & Ortmann, A. & ECON INQ & 1997 \\
\hline Kocenda, E. & J COMP ECON & 2001 & Ortmann, A. & J INST THEOR ECON & 1997 \\
\hline Kolomaznikova, E. & FINANC UVER & 2003 & Ortmann, A. & CAH PSYCHOL COGN & 1997 \\
\hline Komarek, L. & EASTERN EUR ECON & 2000 & Ortmann, A. & J ECON BEHAV ORGAI & 1999 \\
\hline Komarek, L. & EASTERN EUR ECON & 2003 & Ortmann, A. & J ECON BEHAV ORGAI & 2000 \\
\hline Komarek, L. & EASTERN EUR ECON & 2004 & Ortmann, A. & BEHAV BRAIN SCI & 2001 \\
\hline Kostova, D. & WORK EMPLOY SOC & 1999 & Ortmann, A. & BEHAV BRAIN SCI & 2001 \\
\hline Kotlan, V. & EASTERN EUR ECON & 1999 & Ortmann, A. & J ECON PSYCHOL & 2003 \\
\hline Kotlan, V. & FINANC UVER & 2003 & Ortmann, A. & J ECON EDUC & 2003 \\
\hline Kotlan, V. & FINANC UVER & 2005 & Ortmann, A. & BEHAV BRAIN SCI & 2004 \\
\hline Kovacs, B. & POST-COMMUNIST ECON & 2003 & Ortmann, A. & J ECON PSYCHOL & 2004 \\
\hline Kovanda, J. & ECOL ECON & 2003 & Ortmann, A. & J ECON PSYCHOL & 2004 \\
\hline Krc, M. & EKON CAS & 2002 & Ortmann, A. & ECON LETT & 2004 \\
\hline Krejdl, A. & FINANC UVER & 2003 & Ortmann, A. & ECON LETT & 2005 \\
\hline Krejdl, A. & FINANC UVER & 2003 & Ostatnicky, M. & BEHAV BRAIN SCI & 2004 \\
\hline Kubik, A. & EKON CAS & 2000 & Pazdernik, R. & POST-COMMUNIST EC & 2005 \\
\hline Kucerova, Z. & FINANC UVER & 2005 & Pinos, $P$. & EUR J OPER RES & 2002 \\
\hline Kuchar, P. & WORK EMPLOY SOC & 1999 & Podpiera, R. & POLIT EKON & 1999 \\
\hline Kudrna, Z. & POST-COMMUNIST ECON & 2005 & Podpiera, R. & FINANC UVER & 2002 \\
\hline Kulhanek, L. & EASTERN EUR ECON & 2000 & Podpiera, R. & ECON TRANSIT & 2002 \\
\hline Linek, L. & EUR J POLIT RES & 2005 & Podpiera, R. & FINANC UVER & 2003 \\
\hline Lizal, L. & REV ECON STAT & 2001 & Podpiera, R. & J COMP ECON & 2003 \\
\hline Lizal, L. & REV ECON STAT & 2002 & Potluka, O. & EKON CAS & 2004 \\
\hline Lorenz, FO. & J POLIT MIL SOC & 2001 & Pruteanu, A. & EASTERN EUR ECON & 2004 \\
\hline Lorenz, FO. & SOCIOL QUART & 2001 & Rabusic, L. & SOCIOLOGIA & 1997 \\
\hline Lorenz, FO. & SOCIOL EDUC & 2002 & Rodova, V. & EKON CAS & 1997 \\
\hline Maleckova, J. & NEW REPUBLIC & 2002 & Rydval, O. & J ECON PSYCHOL & 2004 \\
\hline Maleckova, J. & J ECON PERSPECT & 2003 & Rydval, O. & ECON LETT & 2004 \\
\hline Manas, M. & EUR J OPER RES & 1995 & Rydval, O. & J ECON PSYCHOL & 2004 \\
\hline Mandel, M. & EASTERN EUR ECON & 2001 & Rydval, O. & ECON LETT & 2005 \\
\hline
\end{tabular}


Table A3: (continued)

\begin{tabular}{|c|c|c|c|c|c|}
\hline Author & Journal & Year & Author & Journal & Year \\
\hline Sakova, Z. & EKON CAS & 1996 & Vecernik, J. & SOCIOL EDUC & 2002 \\
\hline Saroch, S. & POLIT EKON & 2001 & Vecernik, J. & SOCIOL CAS & 2002 \\
\hline Saroch, S. & EASTERN EUR ECON & 2005 & Vecernik, J. & SOCIOL CAS & 2004 \\
\hline Scasny, M. & ECOL ECON & 2003 & Vecernik, J. & FINANC UVER & 2005 \\
\hline Schneider, O. & FINANC UVER & 2003 & Verny, A. & J INST THEOR ECON & 2000 \\
\hline Schneider, O. & FINANC UVER & 2005 & Vintrova, R. & EKON CAS & 1997 \\
\hline Sedmihradsky, M. & INT TAX PUBLIC FINAN & 2001 & Vintrova, $R$. & EUROPE-ASIA STUD & 2004 \\
\hline Singer, $\mathrm{M}$. & REV ECON STAT & 2001 & Visek, JA. & ANN I STAT MATH & 1996 \\
\hline Singer, $M$. & J COMP ECON & 2003 & Visek, JA. & COMPUTATION STAT & 1996 \\
\hline Sirovatka, $\mathrm{T}$. & EASTERN EUR ECON & 2000 & Visek, JA. & COMPUT STAT DATA & 2000 \\
\hline Sirovatka, $\mathrm{T}$. & POLIT EKON & 2003 & Visek, JA. & ANN I STAT MATH & 2002 \\
\hline Sirovatka, $\mathrm{T}$. & FINANC UVER & 2005 & Visek, JA. & SPORT PSYCHOL & 2005 \\
\hline Slavik, M. & FINANC UVER & 2004 & Vitek, L. & PUBLIC ADMIN DEVEL & 2004 \\
\hline Slobodyan, S. & STUD NONLINEAR DYN E & 2001 & Vlcek, K. & J ECONOMETRICS & 2002 \\
\hline Slobodyan, S. & J ECON DYN CONTROL & 2005 & Vosvrda, MS. & EKON CAS & 2001 \\
\hline Smidkova, K. & ECON TRANSIT & 1998 & Vychodil, O. & FINANC UVER & 2005 \\
\hline Smidkova, K. & EASTERN EUR ECON & 1998 & Zajicek, L. & FUND MATH & 2005 \\
\hline Smidkova, K. & EASTERN EUR ECON & 2000 & Zajickova, Z. & EKON CAS & 2004 \\
\hline Smidkova, K. & FINANC UVER & 2005 & Zak, M. & MON LABOR REV & 2004 \\
\hline Sojka, M. & POLIT EKON & 1996 & Zamrazilova, E. & EASTERN EUR ECON & 2000 \\
\hline Sokol, Z. & EASTERN EUR ECON & 1994 & Zeleny, M. & FUND MATH & 1996 \\
\hline Sorm, V. & J COMP ECON & 1999 & Zeleny, M. & PROC AMER MATH SC & 1997 \\
\hline Sorm, V. & J COMP ECON & 2000 & Zeleny, M. & FUND MATH & 2000 \\
\hline Soucek, Z. & EKON CAS & 1997 & Zeleny, M. & PROC AMER MATH SC & 2000 \\
\hline Srholec, M. & EASTERN EUR ECON & 2005 & Zeleny, M. & PROC AMER MATH SC & 2001 \\
\hline Stavarek, D. & FINANC UVER & 2005 & Zeleny, M. & FUND MATH & 2005 \\
\hline Stibal, J. & EASTERN EUR ECON & 1995 & Zeleny, M. & FUND MATH & 2005 \\
\hline Sulc, $Z$. & EASTERN EUR ECON & 1994 & Zeman, $\mathrm{K}$. & EKON CAS & 1997 \\
\hline Svejnar, J. & AM ECON REV & 1996 & Zeman, $\mathrm{K}$. & GENEVA PAP R I-ISS F & 2001 \\
\hline Svejnar, J. & AM ECON REV & 1998 & Zemcik, P. & SOUTH ECON J & 2005 \\
\hline Svejnar, J. & ECON TRANSIT & 1999 & Zemplinerova, A. & OXFORD ECON PAP & 1994 \\
\hline Svejnar, J. & EASTERN EUR ECON & 2000 & Zemplinerova, A. & SMALL BUS ECON & 1995 \\
\hline Svejnar, J. & REV ECON STAT & 2001 & Zemplinerova, A. & EASTERN EUR ECON & 1995 \\
\hline Svejnar, J. & J ECON PERSPECT & 2002 & Zemplinerova, A. & EKON CAS & 1997 \\
\hline Svejnar, J. & REV ECON STAT & 2002 & Zemplinerova, A. & POLIT EKON & 2005 \\
\hline Svejnar, J. & J COMP ECON & 2003 & Zidek, L. & POLIT EKON & 2003 \\
\hline Svejnar, J. & J COMP ECON & 2005 & Zidek, L. & POLIT EKON & 2004 \\
\hline Svejnar, J. & REV ECON STAT & 2005 & Zigic, K. & EUR ECON REV & 1998 \\
\hline Tomek, G. & POLIT EKON & 2004 & Zigic, $\mathrm{K}$. & J DEV ECON & 2000 \\
\hline Tomsik, V. & EASTERN EUR ECON & 2000 & Zmeskal, Z. & EUR J OPER RES & 2001 \\
\hline Tomsik, V. & EASTERN EUR ECON & 2001 & Zmeskal, Z. & EUR J OPER RES & 2005 \\
\hline Tomsik, V. & EASTERN EUR ECON & 2002 & & & \\
\hline Tomsik, V. & EASTERN EUR ECON & 2005 & & & \\
\hline Tosovska, E. & EASTERN EUR ECON & 1995 & & & \\
\hline Tuma, Z. & J COMP ECON & 1994 & & & \\
\hline Tuma, Z. & EASTERN EUR ECON & 1995 & & & \\
\hline Tuma, Z. & EASTERN EUR ECON & 2000 & & & \\
\hline Tuma, $\mathrm{z}$. & ECON TRANSIT & 2002 & & & \\
\hline Turnovec, F. & COMMUNIS POST-COMMUN & 1997 & & & \\
\hline Urban, L. & FINANC UVER & 1999 & & & \\
\hline Uzagalieva, A. & POST-COMMUNIST ECON & 2005 & & & \\
\hline Vancurova, A. & INT TAX PUBLIC FINAN & 2001 & & & \\
\hline Vavra, D. & FINANC UVER & 2002 & & & \\
\hline Vavra, D. & ECON TRANSIT & 2003 & & & \\
\hline Vavrejnova, M. & EASTERN EUR ECON & 1995 & & & \\
\hline Vecernik, J. & RURAL SOCIOL & 1999 & & & \\
\hline Vecernik, J. & COMMUNIS POST-COMMUN & 1999 & & & \\
\hline Vecernik, J. & POLIT EKON & 2000 & & & \\
\hline Vecernik, J. & J POLIT MIL SOC & 2001 & & & \\
\hline Vecernik, J. & SOCIOL QUART & 2001 & & & \\
\hline
\end{tabular}


Individual researchers, as well as the on-line and printed versions of the CERGE-EI Working Papers (including their dissemination) were supported from the following institutional grants:

- Economic Aspects of EU and EMU Entry [Ekonomické aspekty vstupu do Evropské unie a Evropské měnové unie], No. AVOZ70850503, (2005-2010);

- Economic Impact of European Integration on the Czech Republic [Ekonomické dopady evropské integrace na ČR], No. MSM0021620846, (2005-2011);

Specific research support and/or other grants the researchers/publications benefited from are acknowledged at the beginning of the Paper.

(c) Daniel Münich, 2006

All rights reserved. No part of this publication may be reproduced, stored in a retrieval system or transmitted in any form or by any means, electronic, mechanical or photocopying, recording, or otherwise without the prior permission of the publisher.

Published by

Charles University in Prague, Center for Economic Research and Graduate Education (CERGE) and

Economics Institute (EI), Academy of Sciences of the Czech Republic

CERGE-EI, Politických vězñu 7, 11121 Prague 1, tel.: +420 224005 153, Czech Republic.

Printed by CERGE-EI, Prague

Subscription: CERGE-El homepage: http://www.cerge-ei.cz

Editors: Directors of CERGE and EI

Managing editors: Deputy Directors for Research of CERGE and EI

ISSN 1211-3298

ISBN 80-7343-096-7 (Univerzita Karlova. Centrum pro ekonomický výzkum a doktorské studium) ISBN 80-7344-085-7 (Akademie věd České republiky. Národohospodářský ústav) 
CERGE-EI

P.O.BOX 882

Politických vězňů 7

11121 Praha 1

Czech Republic http://www.cerge-ei.cz 